\title{
Vasoactive intestinal polypeptide- and pituitary adenylate cyclase activating polypeptide-mediated control of catecholamine release from chromaffin tissue in the rainbow trout, Oncorhynchus mykiss
}

\author{
C J Montpetit and S F Perry \\ Department of Biology, University of Ottawa, 30 Marie Curie, Ottawa, Ontario K1N 6N5, Canada \\ (Requests for offprints should be addressed to S F Perry; Email: sfperry@science.uottawa.ca)
}

\begin{abstract}
The aim of the present investigation was to assess the relative contributions of cholinergic (acetylcholine) and non-cholinergic vasoactive intestinal polypeptide (VIP), and pituitary adenylate cyclase activating polypeptide (PACAP) neurotransmitters in the neuronal control of catecholamine secretion from the chromaffin tissue lining the posterior cardinal vein of the rainbow trout (Oncorhynchus mykiss). Using an in situ saline-perfused posterior cardinal vein preparation, it was demonstrated that exogenous administration of chicken VIP or human PACAP-27 caused a dose-dependent increase in adrenaline secretion; noradrenaline secretion was unaffected. Analysis of dose-response curves indicated that VIP and PACAP stimulated the secretion of adrenaline with a similar degree of potency $\left(\mathrm{ED}_{50}\right.$ for $\mathrm{VIP}=1.90 \times 10^{-11}$ $\mathrm{mol} / \mathrm{kg} ; \mathrm{ED}_{50}$ for PACAP $=1.03 \times 10^{-11} \mathrm{~mol} / \mathrm{kg}$ ). The VIP/PACAP-elicited secretion was diminished in the presence of the VIP receptor antagonist, VIP 6-28, but was unaffected by the PACAP receptor antagonist, PACAP 6-27, or the cholinergic antagonists, hexamethonium and atropine. Thus, this is the first study to
\end{abstract}

demonstrate a direct stimulatory role for VIP or PACAP in catecholamine secretion from piscine chromaffin cells.

The relative contribution of cholinergic and noncholinergic neurotransmitters in the neuronal control of catecholamine secretion from the chromaffin tissue was evaluated using an in situ nerve-stimulating technique previously validated by us in the rainbow trout. This was accomplished by comparing catecholamine secretion in the presence or absence of cholinergic and the VIP and PACAP receptor antagonists during different levels of electrical stimulation. The results demonstrated that cholinergic stimulation predominated during high frequency of electrical stimulation $(20 \mathrm{~Hz})$ while the noncholinergic component prevailed at low frequency $(1 \mathrm{~Hz})$. Overall, the results of the present investigation demonstrate that VIP and/or PACAP may directly stimulate adrenaline secretion from trout chromaffin cells at low levels of neuronal activity. Therefore, the neuronal control of catecholamine secretion in teleosts may not be confined to cholinergic-evoked events.

Journal of Endocrinology (2000) 166, 705-714

\section{Introduction}

During conditions of acute severe stress, rainbow trout and several other teleosts release the catecholamine hormones, adrenaline and noradrenaline, into the circulation (Wendelaar-Bonga 1997, Reid et al. 1998). The subsequent rise in plasma catecholamine levels is believed to modulate a series of physiological responses that serve to enhance cardio-respiratory function and metabolism (Randall \& Perry 1992, Epple 1993, Fabbri et al. 1998). In teleost fish, the secretion of catecholamines from chromaffin tissue, located within the walls of the posterior cardinal vein (PCV) (Nandi 1961, Gallo et al. 1993), is under the control of numerous physiological stimuli including signals of humoral, neuronal and autocrine/paracrine origin (Reid et al. 1998). Although several factors are known to initiate catecholamine secretion, increased neuronal activity of preganglionic sympathetic nerve fibres is thought to be the predominant mechanism for catecholamine secretion during stress (Epple et al. 1995, Reid et al. 1998).

The current model for the neuronal control of catecholamine secretion in fish advocates that a number of non-cholinergic neurotransmitters and/or neuromodulators are co-released with acetylcholine during neuronal activity (Reid \& Perry 1995, Abele et al. 1998, Montpetit \& Perry 1999). However, this model has not been tested empirically and thus the role of non-cholinergic neurotransmitters in controlling catecholamine secretion in fish is unknown. Reid et al. (1995), using immunocytochemistry, identified a number of neurotransmitters or neuropeptides, including vasoactive intestinal polypeptide (VIP) and pituitary adenylate cyclase activating polypeptide (PACAP) in nerve fibres innervating the chromaffin tissue of Atlantic cod (Gadus morhua), rainbow trout 
(Oncorhynchus mykiss), American eel (Anguilla anguilla) and dogfish (Squalus acanthias). While VIP and PACAP mediation of catecholamine secretion have been demonstrated in non-piscine chromaffin cells (Misbahuddin et al. 1988, Yamaguchi 1993, Guo \& Wakade 1994, Yon et al. 1994, Watanabe et al. 1995, Tanaka et al. 1996), their involvement in fish is unresolved. Thus, the goal of the first component of this study was to determine whether the neuropeptides VIP and PACAP are able to directly stimulate the secretion of catecholamines from the chromaffin tissue in rainbow trout.

A recent study (Montpetit \& Perry 1999) demonstrated that blockade of chromaffin cell cholinergic (nicotinic and muscarinic) receptors failed to completely inhibit the neuronally induced secretion of adrenaline and noradrenaline in rainbow trout. Consequently, the participation of unspecified non-cholinergic neurotransmitters was suggested. Thus, a second goal of the present investigation was to assess the relative contribution of cholinergic and non-cholinergic mechanisms in the control of catecholamine secretion from trout chromaffin cells during neuronal stimulation and to identify the contributing non-cholinergic neurotransmitters. This was accomplished by comparing catecholamine secretion in the presence or absence of cholinergic or VIP/PACAP receptor antagonists during neuronal stimulation of chromaffin tissue in situ.

\section{Materials and Methods}

Rainbow trout Oncorhynchus mykiss (Walbaum) of both sexes were obtained from Linwood Acres Trout Farm (Campbellcroft, ON, Canada) and held in large fibreglass tanks supplied with dechlorinated city of Ottawa tapwater maintained at $13{ }^{\circ} \mathrm{C}$. They were allowed to acclimate to the aquaria for at least 3 weeks before experimentation. Fish were maintained on a photoperiod of $12 \mathrm{~h}$ light: $12 \mathrm{~h}$ darkness and fed daily to satiation with a commercial fish diet.

\section{In situ saline-perfused $P C V$ preparation}

Fish were killed by a blow to the head, weighed and place on ice ventral side up. A ventral incision was made along the entire length of the animal and the tissue overlying the heart was removed by blunt dissection to expose the ventricle and the bulbus arteriosis. The PCV and ventricle were catheterized (Clay-Adams, PE 160 polyethylene tubing; UWR, Mississauga, Ontario, Canada) and served as the inflow and outflow respectively of the perfusion fluid. Each preparation was perfused for $20 \mathrm{~min}$ with modified aerated Cortland saline (Wolf 1963) (125 mM $\mathrm{NaCl}, 2 \cdot 0 \mathrm{mM} \mathrm{KCl}, 2 \cdot 0 \mathrm{mM} \mathrm{MgSO}_{4}, 5 \cdot 0 \mathrm{mM} \mathrm{NaHCO}_{3}$, $7 \cdot 5 \mathrm{mM}$ glucose, $2 \cdot 0 \mathrm{CaCl}_{2}$ and $1.25 \mathrm{mM} \mathrm{KH}_{2} \mathrm{PO}_{4}$, final $\mathrm{pH} 7 \cdot 8$ ) to allow catecholamine secretion to stabilize.
Perfusion was accomplished from a positive pressure difference between the surface of the saline and the outflow cannula, which resulted in a flow rate of approximately $1.5 \mathrm{ml} / \mathrm{min}$.

After the stabilization period, a control pre-stimulation sample was collected in a pre-weighed microcentrifuge tube to assess basal catecholamine secretion rate. After collection of the pre-stimulation sample, a bolus injection of agonist or electrical stimulation was given to preparations in accordance with the treatments described below. Agonists were delivered by a bolus injection through a three-way valve connected to the inflow catheter. A period of 1 min was allowed for the drug to be delivered to the chromaffin tissue before post-stimulation samples were collected at 1, 2, 3, 4 and 5 min after intervention. All samples were frozen at $-80{ }^{\circ} \mathrm{C}$ until determination of catecholamine levels. Perfusate samples were reweighed before catecholamine analysis to permit an estimation of perfusion flow rates and thus to allow the calculation of catecholamine secretion rates.

\section{Field stimulation protocol}

Fish were electrically stimulated using a previously validated field stimulation technique (Montpetit \& Perry 1999). A pair of electrodes, connected to a Grass SD-9 stimulator (Grass Instruments, Quincy, MA, USA), was sutured to the body wall on either side of the fish in the anterior region of the PCV. After collection of the pre-stimulation sample, each preparation was given a single stimulation. Field stimulation was carried out at $60 \mathrm{~V}, 1 \mathrm{~ms}$ in duration for a period of $30 \mathrm{~s}$ and collection of post-stimulation samples began immediately at the onset of stimulation.

\section{VIP- and PACAP-induced catecholamine secretion}

Series 1: VIP- and PACAP-evoked catecholamine release and dose-response curves To characterize the effects of exogenous ckVIP (chicken VIP; Peninsula Laboratories Inc.) and hPACAP-27 (PACAP-27-NH human, ovine, rat; Peninsula Laboratories, San Carlos, CA, USA) on catecholamine secretion, preparations were given a single bolus injection (final volume, $0.3 \mathrm{ml}$ ) of VIP or PACAP-27, at doses ranging from $10^{-13}$ to $5 \times 10^{-8}$ $\mathrm{mol} / \mathrm{kg}$ body mass $(n=6-10$ for each dose). In these experiments, only adrenaline secretion was significantly elevated over baseline levels and therefore only doseresponse curves for ckVIP- and hPACAP-27-induced adrenaline secretion were constructed. Generally, peak secretion rates were obtained in the second or third minute after agonist administration. Therefore, dose-response curves for ckVIP- or hPACAP-27-elicited adrenaline secretion were constructed that expressed peak catecholamine secretion rates as a function of dose. The doses of ckVIP and hPACAP-27 required to cause half-maximal 
release $\left(\mathrm{ED}_{50}\right)$ were calculated from Hill plots of $\log (\%$ of maximal secretion $/ 100-\%$ of maximal secretion) versus $\log$ dose. Only those values falling between 5 and 95\% were used.

Series 2: effects of VIP 6-28, PACAP 6-27, and cholinergic antagonists on VIP- and PACAP-27evoked catecholamine secretion Experiments were performed to evaluate the effects of ckVIP and hPACAP-27 on catecholamine secretion in the presence or absence of VIP (VIP 6-28; Peninsula Laboratories), and PACAP (PACAP 6-27; Peninsula Laboratories), and cholinergic receptor (hexamethonium plus atropine (Sigma, Oaksville, Ontario, Canada)) antagonists. PACAP 6-27 and VIP 6-28 were chosen on the basis of their potent antagonism of PACAP type I (Robberecht et al. 1991, Gaspo et al. 1997) and PACAP type II (or VIP) receptors (Bodanszky et al. 1973, Fishbein et al. 1994) respectively. In a first experimental series, different preparations were given a bolus injection $(0.6 \mathrm{ml})$ of ckVIP $\left(10^{-10} \mathrm{~mol} / \mathrm{kg}\right)(n=6)$, a cocktail $(0.6 \mathrm{ml})$ containing ckVIP $\left(10^{-10} \mathrm{~mol} / \mathrm{kg} ; 0 \cdot 3 \mathrm{ml}\right)$ plus VIP $6-28$ $\left(10^{-6} \mathrm{M} ; 0.3 \mathrm{ml}\right)(n=6)$, a cocktail $(0.6 \mathrm{ml})$ containing ckVIP $\left(10^{-10} \mathrm{~mol} / \mathrm{kg} ; 0.3 \mathrm{ml}\right)$ and a mixture of hexamethonium $\left(10^{-3} \mathrm{M}\right)$ plus atropine $\left(10^{-5} \mathrm{M}\right)(0 \cdot 3 \mathrm{ml})$ $(n=6)$ or a cocktail $(0.6 \mathrm{ml})$ containing ckVIP $\left(10^{-10}\right.$ $\mathrm{mol} / \mathrm{kg} ; 0 \cdot 3 \mathrm{ml})$ plus PACAP $6-27\left(10^{-8} \mathrm{M} ; 0.3 \mathrm{ml}\right)$ $(n=6)$. Similarly, in a second experimental series, preparations were given a bolus injection $(0.6 \mathrm{ml})$ containing hPACAP-27 $\left(10^{-10} \mathrm{~mol} / \mathrm{kg}\right)$ or hPACAP-27 $\left(10^{-10}\right.$ $\mathrm{mol} / \mathrm{kg} ; 0.3 \mathrm{ml})$ in combination with the antagonists described above $(0.3 \mathrm{ml})$. In a third set of experiments, bolus injections $(0.6 \mathrm{ml})$ of the VIP or PACAP-27 receptor antagonists, VIP 6-28 $\left(10^{-6} \mathrm{M}\right)$ and PACAP 6-27 $\left(10^{-8} \mathrm{M}\right)$ respectively, were administered to preparations to confirm that they were not acting as peptidergic agonists. Each preparation received a single injection.

Series 3: effects of cholinergic receptor antagonists, and of VIP 6-28 on carbachol-elicited catecholamine secretion This series of experiments was performed to confirm the specificity of the various drugs. Preparations were given as a bolus injection $(0 \cdot 3 \mathrm{ml})$ of either $10^{-5} \mathrm{~mol} / \mathrm{kg}$ carbachol (non-specific cholinergic receptor agonist; Sigma) or carbachol in combination with a cocktail $(0.3 \mathrm{ml})$ of hexamethonium (nicotinic receptor antagonist; $10^{-3} \mathrm{M}$ ) plus atropine (muscarinic receptor antagonist; $\left.10^{-5} \mathrm{M}\right)(0 \cdot 3 \mathrm{ml})$. Additionally, preparations were given as a bolus injection of carbachol in combination with VIP 6-28 $\left(10^{-6} \mathrm{M}\right)$.

Series 4: contribution of cholinergic versus noncholinergic neurotransmitters on catecholamine secretion To compare catecholamine secretion in the presence or absence of cholinergic and non-cholinergic receptor antagonists during low and high levels of neuronal activity, it was first necessary to establish frequencyresponse curves. Each preparation was given a single electrical stimulation (see above), at frequencies ranging from 0 to $20 \mathrm{~Hz}$.

This series of experiments was performed to determine the relative contribution of cholinergic and noncholinergic neurotransmitters on catecholamine secretion at different levels of neuronal activity. To accomplish this, each preparation was electrically stimulated (see above) only once at a low $(1 \mathrm{~Hz})$ or high $(20 \mathrm{~Hz})$ frequency of stimulation, in the presence or absence of cholinergic and VIP receptor antagonists. Preparations were perfused with control saline for 15-20 min, followed by a switch to saline containing VIP 6-28 $\left(10^{-6} \mathrm{M}\right)$, prior to electrical stimulation. Given the observation that PACAP 6-27 was without effect on either VIP- or PACAP-elicited adrenaline secretion, only the effects of the VIP receptor antagonist, VIP 6-28, on catecholamine secretion were evaluated.

\section{Analytical procedures}

Perfusate catecholamine levels were determined on alumina-extracted samples using HPLC with electrochemical detection (Woodward 1982). 3,4Dihydroxybenzalamine hydrobromide was used as an internal standard.

\section{Statistical analysis}

The data are presented as means \pm 1 S.E.M. Where appropriate, the data were analysed statistically using one-way repeated measures ANOVA followed by Dunnett's test for multiple comparison with pre-stimulation values. In other instances, a one-way ANOVA followed by Dunnett's test for multiple comparisons was performed; if the normality test failed, an ANOVA on ranks was performed followed by Dunnett's test for multiple comparisons. The fiducial limits of significance were set at $5 \%$. Significance of $\mathrm{ED}_{50}$ values was determined by calculating the $95 \%$ confidence intervals of the Hill plot regressions (SigmaPlot 4.0; Sigma). All statistical tests were performed using a commercial statistical software package (SigmaStat; Jandel Scientific, version 2.03; Sigma).

\section{Results}

VIP- and PACAP-induced catecholamine secretion

Series 1: VIP- and PACAP-induced catecholamine secretion and dose-response curves Figure 1 illustrates the temporal effects of bolus injections of ckVIP or hPACAP-27 on catecholamine secretion. Significant increases in adrenaline secretion were observed in response to exogenous ckVIP (Fig. 1A) and hPACAP-27 (Fig. 1B) 

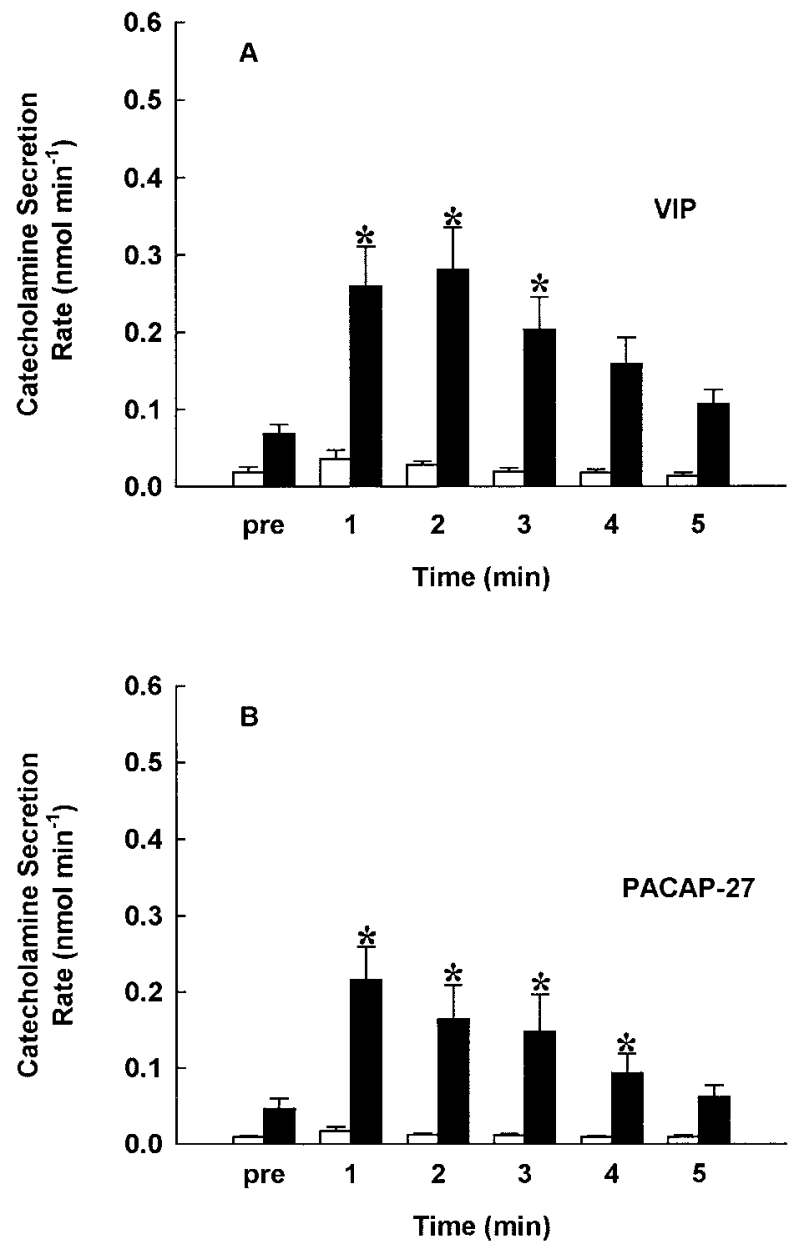

Figure 1 In situ adrenaline (filled columns) and noradrenaline (unfilled columns) secretion rates in response to bolus injections of (A) VIP $\left(10^{-9} \mathrm{~mol} / \mathrm{kg} ; n=6\right)$ and (B) PACAP-27 $\left(10^{-10} \mathrm{~mol} / \mathrm{kg}\right.$; $n=6$ ). Values are shown as means \pm 1 S.E.M. An asterisk denotes a significant difference from the pre-stimulation (Pre) value $(P<0 \cdot 05)$.

within $1 \mathrm{~min}$ of injection. The increases in adrenaline secretion caused by ckVIP and hPACAP-27 were dosedependent (Fig. 2). $\mathrm{ED}_{50}$ values obtained from the doseresponse curves revealed that exogenous ckVIP and hPACAP-27 stimulated adrenaline secretion with similar potency. The $\mathrm{ED}_{50}$ values for adrenaline secretion were $1.91 \times 10^{-11}$ and $1.03 \times 10^{-11} \mathrm{~mol} / \mathrm{kg}$ for ckVIP and hPACAP-27 respectively. Noradrenaline secretion was unaffected by either neuropeptide at all of the doses tested.

Series 2: effects of VIP 6-28, PACAP 6-27 and cholinergic receptor antagonists on VIP- and PACAP-27-evoked adrenaline secretion The addition of VIP 6-28 (VIP receptor antagonist) caused significant reductions in adrenaline secretion rates in response to ckVIP (Fig. 3) or hPACAP-27 (Fig. 4);

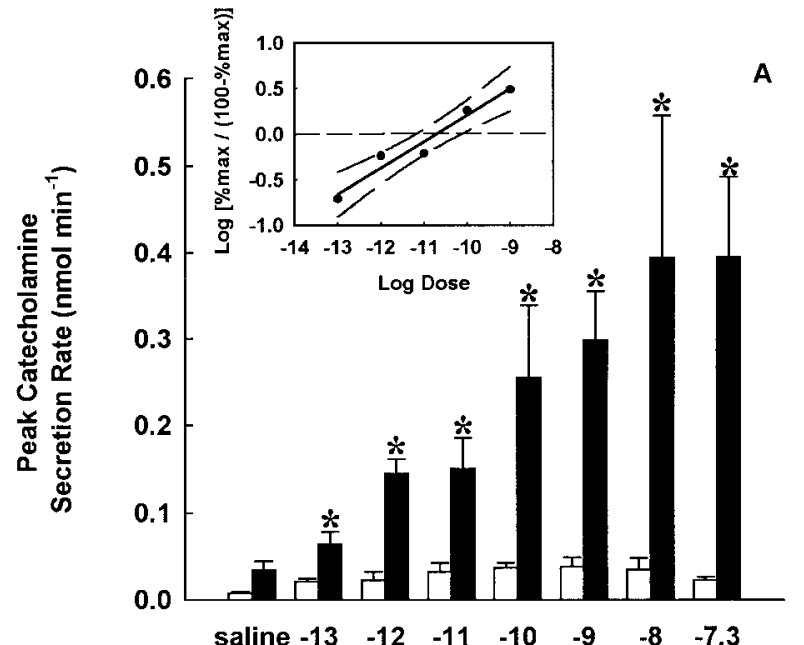

Log VIP dose $\left(\mathrm{mol} \mathrm{kg}^{-1}\right)$

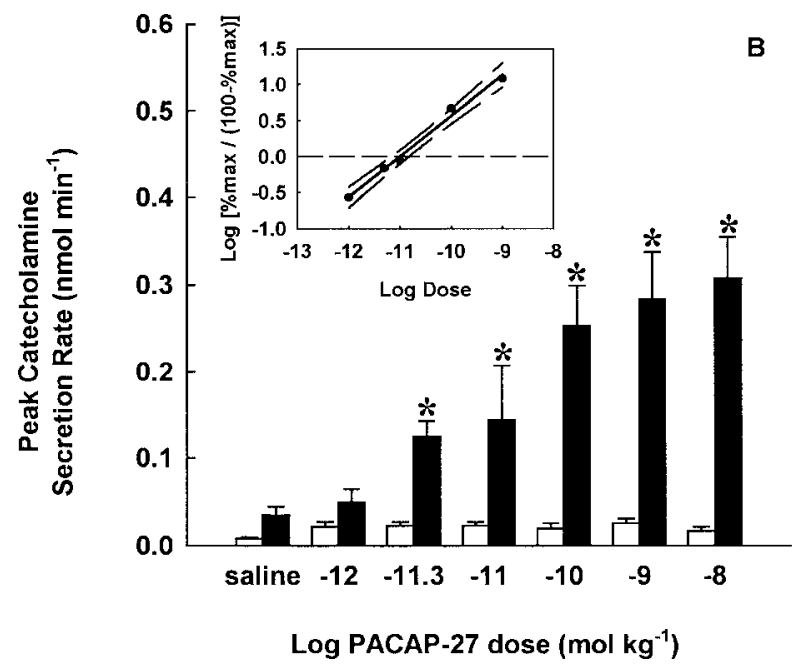

Figure 2 In situ peak adrenaline (filled columns) and noradrenaline (unfilled columns) secretion rates in response to bolus injections of (A) VIP and (B) PACAP-27. Values are shown as means \pm 1 S.E.M. ( $n=6-10$ different fish for each dose administered). An asterisk denotes a significant difference in peak secretion when compared with the saline-injected group $(P<0 \cdot 05)$. Inserts, doses of ckVIP (A) and hPACAP-27 (B) required to cause half-maximal release $\left(E D_{50}\right)$ were calculated from Hill plots that expressed log (\% of maximal secretion $/ 100-\%$ of maximal secretion) versus log dose. The regression equations and $\mathrm{ED}_{50} \mathrm{~s}$ are: for VIP, $y=0.298 x+3 \cdot 11, r=0.98, E_{50}=1.90 \times 10^{-11} \mathrm{~mol} / \mathrm{kg}$; for PACAP, $y=0.5666 x+6 \cdot 23, r=0.99, E_{50}=1.03 \times 10^{-11} \mathrm{~mol} / \mathrm{kg}$.

however, PACAP 6-27 (PACAP receptor antagonist) was without effect. Blockade of the cholinergic receptor (using hexamethonium plus atropine) did not affect the ckVIPand hPACAP-27-evoked secretion of adrenaline. VIP 6-28 or PACAP 6-27, alone, did not affect adrenaline secretion (Figs 3 and 4). 


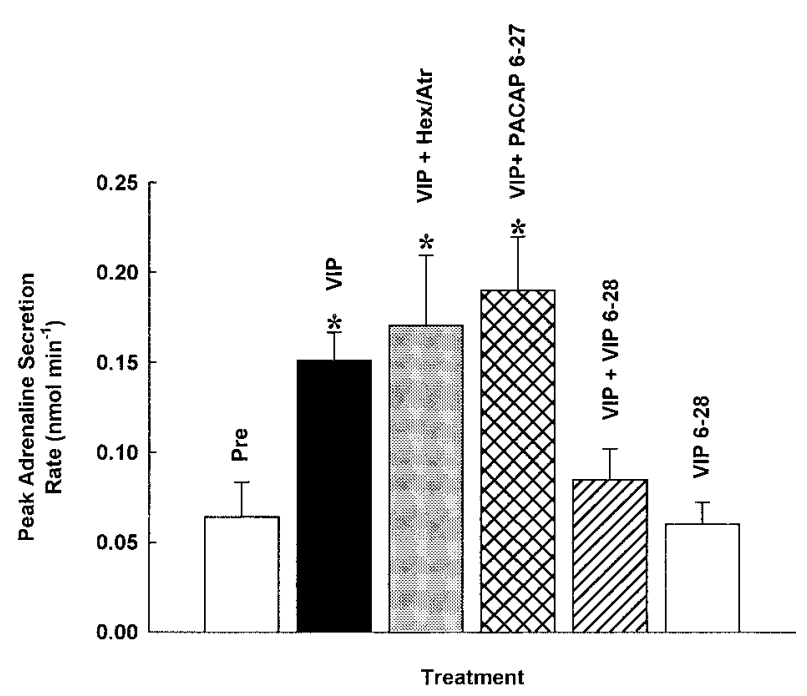

Figure 3 The effects of bolus injections of VIP $\left(10^{-9} \mathrm{~mol} / \mathrm{kg}\right.$, black column, $n=6)$, and VIP $\left(10^{-9} \mathrm{~mol} / \mathrm{kg}\right)$ in combination with hexamethonium (Hex) $\left(10^{-3} \mathrm{M}\right)$ plus atropine (Atr) $\left(10^{-5} \mathrm{M}\right)$ (grey column, $n=6)$, PACAP $6-27\left(10^{-8} \mathrm{M}\right)$ (cross hatched column, $n=6)$, or VIP $6-28\left(10^{-6} \mathrm{M}\right)$ (hatched column, $\left.n=6\right)$ on in situ adrenaline secretion rates. In addition, the effect of bolus injections of VIP $6-28\left(10^{-6} \mathrm{M}\right)$ (unfilled column, $\left.n=6\right)$ alone was evaluated. Values are shown as means \pm 1 S.E.M. An asterisk denotes a significant difference from pre-stimulation (Pre) values $(P<0 \cdot 05)$.

Series 3: effects of cholinergic receptor antagonists and of VIP 6-28 on carbachol-elicited catecholamine secretion Carbachol-evoked adrenaline or noradrenaline secretion in the presence of a cocktail of hexamethonium and atropine was markedly diminished (Fig. 5). Because PACAP 6-27 had no effect on ckVIPand hPACAP-27-elicited release, only the effect of VIP 6-28 on carbachol-evoked release was evaluated; VIP 6-28 did not alter the cholinergic secretion of either catecholamine (Fig. 5).

Series 4: contribution of cholinergic versus noncholinergic neurotransmitters on catecholamine secretion Catecholamine secretion during field stimulation, in situ, was frequency-dependent (Fig. 6). Significant elevation of the rate of adrenaline and noradrenaline secretion occurred at $1 \mathrm{~Hz}$ and reached a maximum at 10 $\mathrm{Hz}$. Given that $1 \mathrm{~Hz}$ elicited significant increases in catecholamine secretion and that $20 \mathrm{~Hz}$ induced maximal secretion, these frequencies were chosen for subsequent experiments to evaluate the relative contribution of noncholinergic neurotransmitters during high and low levels of neuronal activity.

To evaluate the involvement of cholinergic and noncholinergic neurotransmitters at different levels of neuronal activity, preparations were stimulated at low (1 $\mathrm{Hz}$ ) or high $(20 \mathrm{~Hz})$ frequencies in the presence or absence of cholinergic receptor blockade (using hexamethonium

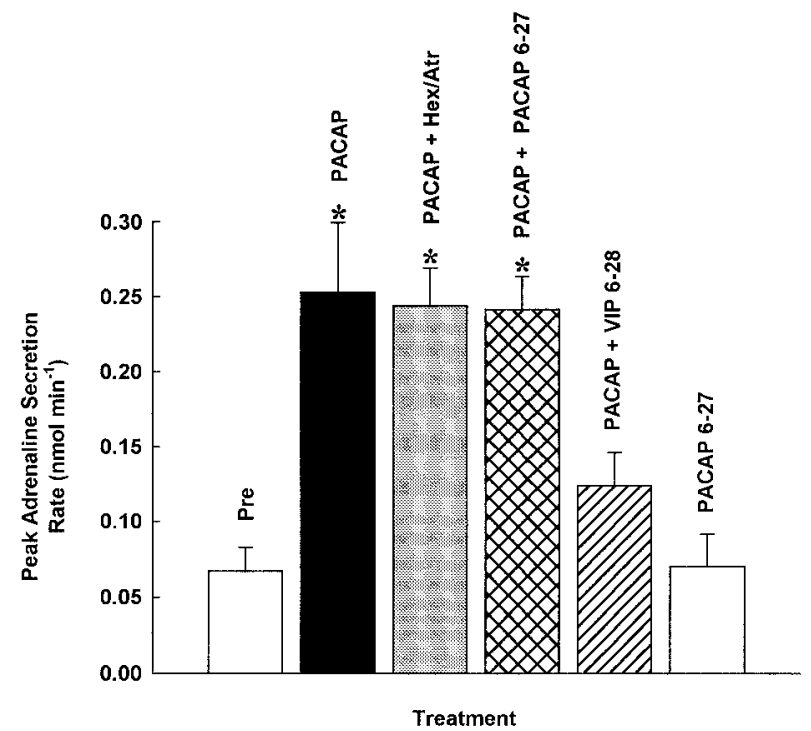

Figure 4 The effects of bolus injections of PACAP-27 $\left(10^{-10} \mathrm{~mol} / \mathrm{kg}\right)$ (black column, $n=6)$, and PACAP-27 $\left(10^{-10} \mathrm{~mol} / \mathrm{kg}\right)$ in combination with hexamethonium (Hex) plus atropine (Atr) (grey column, $n=6)$, PACAP $6-27\left(10^{-8} \mathrm{M}\right)$ (cross hatched column, $n=6)$, or VIP $6-28\left(10^{-6} \mathrm{M}\right)$ (hatched column, $\left.n=6\right)$ on in situ adrenaline secretion rates. In addition, the effect of bolus injections of PACAP $6-27\left(10^{-8} \mathrm{M}\right)$ (unfilled column, $n=6$ ) alone was evaluated. Values are shown as means \pm 1 S.E.M. An asterisk denotes a significant difference from pre-stimulation (Pre) values $(P<0 \cdot 05)$.

plus atropine) or VIP receptor blockade (using VIP 6-28) (Fig. 7). Given the inability of PACAP 6-27 to reduce the VIP- and PACAP-elicited adrenaline secretion, only VIP 6-28 was used in this series of experiments. During stimulation carried out at $1 \mathrm{~Hz}$, noradrenaline secretion was significantly reduced in preparations perfused with saline containing hexamethonium plus atropine. In preparations perfused with saline containing VIP $6-28$, both the rates of noradrenaline and adrenaline secretion were significantly reduced. At $20 \mathrm{~Hz}$, the rates of noradrenaline and adrenaline secretion were significantly reduced in preparations perfused with saline containing hexamethonium plus atropine. In preparations perfused with saline containing VIP 6-28, secretion of both catecholamines was unaffected.

\section{Discussion}

In fish, the neuropeptides VIP and PACAP are found throughout the central and peripheral nervous systems. VIP and PACAP have been implicated as neurotransmitters or neuromodulators in the control of various physiological processes including cardiovascular function, respiration, digestion and glandular secretions (Holmgren 1985, 1995, Dimaline et al. 1987, Aldman \& Holmgren 

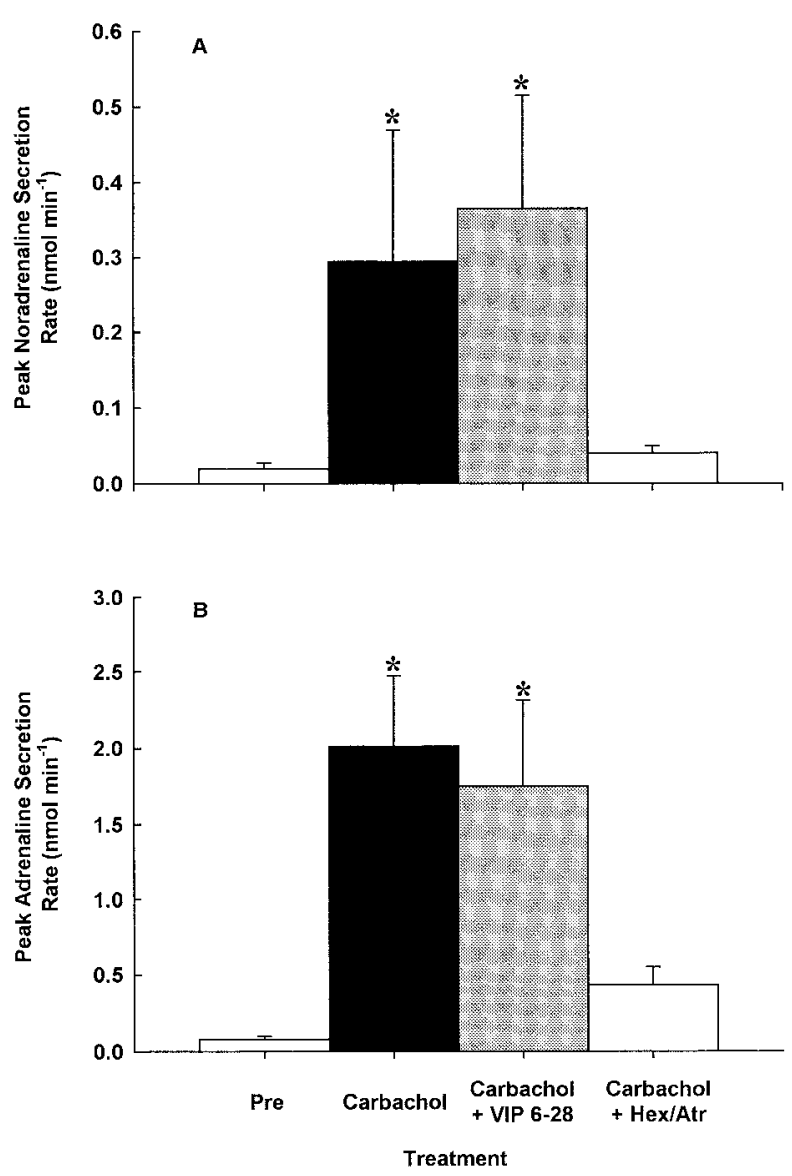

Figure 5 The effects of bolus injections of carbachol $\left(10^{-5}\right.$ $\mathrm{mol} / \mathrm{kg}$, black columns, $n=6)$, and carbachol $\left(10^{-5} \mathrm{~mol} / \mathrm{kg}\right)$ in combination with VIP $6-28\left(10^{-6} \mathrm{M}\right)$ (grey columns, $\left.n=6\right)$ or hexamethonium (Hex) $\left(10^{-3} \mathrm{M}\right)$ plus atropine (Atr) $\left(10^{-5} \mathrm{M}\right)$ (unfilled columns, $n=6$ ), on in situ (A) noradrenaline and (B) adrenaline secretion rates. Values are shown as means \pm 1 S.E.M. An asterisk denotes a significant difference from pre-stimulation (Pre) values $(P<0 \cdot 05)$.

1992, Wong et al. 1998). On the basis of the results of the present investigation, a role for VIP and/or PACAP can be extended to the regulation of catecholamine secretion from chromaffin cells in the rainbow trout.

\section{Direct effects of exogenous VIP and PACAP on in situ catecholamine secretion}

The ability of the neuropeptides VIP and PACAP to directly stimulate the secretion of adrenaline from piscine chromaffin cells is reported for the first time. In agreement with prior studies using non-piscine vertebrates (Misbahuddin et al. 1988, Wakade et al. 1991, Isobe et al. 1993, Guo \& Wakade 1994, Yon et al. 1994, Watanabe et al. 1995), bolus injections of VIP or PACAP caused a dose-dependent release of adrenaline from the chromaffin tissue associated with the PCV. The $\mathrm{ED}_{50}$ values for

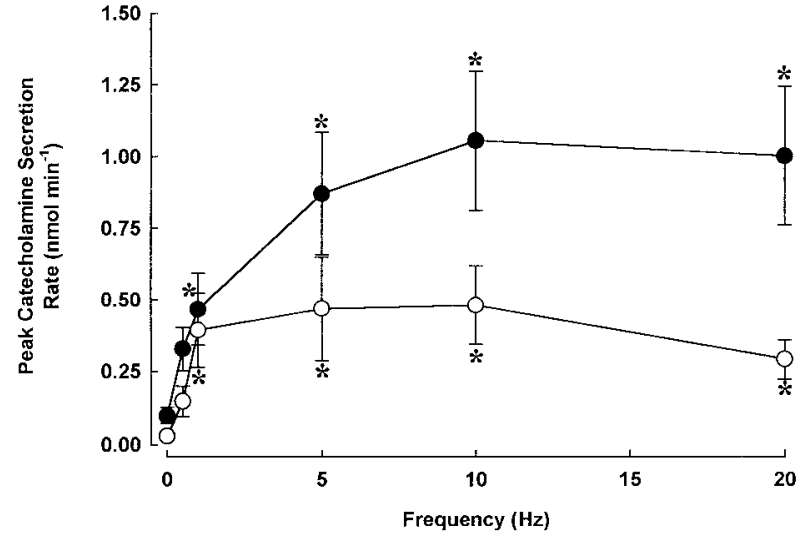

Figure 6 Frequency-response curve for adrenaline $(\mathbf{0})$ and noradrenaline $(\bigcirc)$ secretion rates. Each preparation was stimulated at different frequencies of stimulation for a period of $30 \mathrm{~s}$ at $60 \mathrm{~V}$ and for 1 ms. Values are shown as means \pm 1 s.E.M. ( $n=6$ fish for each frequency). An asterisk denotes a significant difference from non-stimulated values $(0 \mathrm{~V})(P<0 \cdot 05)$.

ckVIP and hPACAP-27 showed that both neuropeptides were able to stimulate adrenaline secretion with a similar degree of potency. The results also indicated that the increase in adrenaline secretion in response to VIP or PACAP was significantly reduced by the VIP receptor antagonist, VIP 6-28, but unaffected by the PACAP receptor antagonist, PACAP 6-27, or the cholinergic receptor antagonists, hexamethonium and atropine. Thus, the results of this study suggest that the neuronal control of trout chromaffin cell activity may include both cholinergic and peptidergic components (see below).

In agreement with prior studies conducted in several teleosts including rainbow trout, American eel, Atlantic cod and the common carp (Nilsson et al. 1976, Fritsche et al. 1993, Reid \& Perry 1995, Al-Kharrat et al. 1997, Gfell et al. 1997, Montpetit \& Perry 1999), the carbacholevoked elevation of adrenaline and noradrenaline secretion was significantly reduced in the presence of hexamethonium (nicotinic receptor antagonist) and atropine (muscarinic receptor antagonists). Because cholinoceptor blockade did not affect ckVIP- or hPACAP-27-evoked adrenaline secretion, it was clear that the effects of the neuropeptides on trout chromaffin cells occur independently of cholinergic stimulation. Moreover, the observation that the VIP receptor antagonist, VIP 6-28, significantly attenuated the ckVIP- and hPACAP-27elicited secretion of adrenaline indicates that these neuropeptides specifically stimulate VIP receptors. In accord with prior studies, the secretory profile during cholinergic stimulation includes the release of both adrenaline and noradrenaline (Fritsche et al. 1993, Montpetit \& Perry 1999). VIP and PACAP, however, preferentially stimulated the secretion of adrenaline (see also Guo \& Wakade 1994). These findings imply that the variations in the 

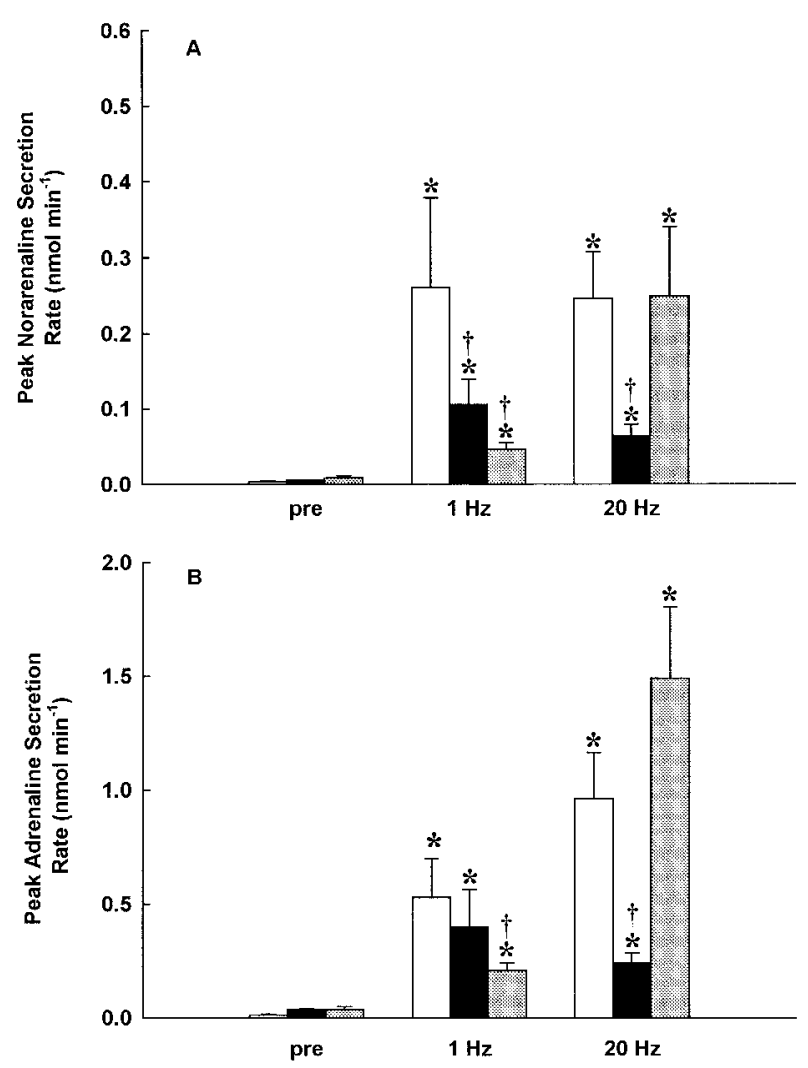

Figure 7 The effects of pre-treatment with saline $(n=6$, unfilled columns), saline containing hexamethonium $\left(10^{-3} \mathrm{M}\right)$ plus atropine $\left(10^{-5} \mathrm{M}\right)(n=6$, black columns), or saline containing VIP $6-28\left(10^{-6} \mathrm{M}\right)(n=6$, grey columns) on in situ (A) noradrenaline and (B) adrenaline secretion rates in response to low $(1 \mathrm{~Hz})$ and high $(20 \mathrm{~Hz})$ frequencies of stimulation. Values are shown as means \pm 1 S.E.M. An asterisk denotes a significant difference from the pre-stimulation (Pre) values $(P<0 \cdot 05)$; a dagger denotes a significant difference from the control saline-treated group $(P<0 \cdot 05)$.

secretion of adrenaline and noradrenaline in response to acetylcholine and VIP/PACAP may not reflect their potency but their ability to specifically stimulate adrenaline- versus noradrenaline-containing chromaffin cells.

In the present study, PACAP-27 and VIP were equipotent in stimulating adrenaline secretion. This is in marked contrast to the situation in non-piscine chromaffin cells where PACAP is 1000 times more potent than VIP (Wakade et al. 1991, Watanabe et al. 1992, 1995, Isobe et al. 1993, Guo \& Wakade 1994). It has been previously demonstrated in fish and higher vertebrates that two different types of receptors may mediate the biological effects of VIP and PACAP. PACAP type I receptors have a much greater affinity for PACAP (1000 times) than VIP, whereas the PACAP type II receptors (classically known as VIP receptors) recognize both VIP and PACAP with similar affinity (Chow 1997, Wei et al. 1998, Wong et al.
1998). In mammals, the adrenal medulla exhibits a pronounced expression of the PACAP type I receptor, while the PACAP type II receptor is not detected (Watanabe et al. 1992, Spengler et al. 1993). Yet, given the fact that both VIP and PACAP elicited the secretion of adrenaline with equipotency, and that the VIP receptor antagonist (VIP 6-28) reduced secretion in response to both neuropeptides, it appears that in rainbow trout the VIP- and PACAP-elicited secretion of adrenaline may be mediated by PACAP type II (VIP) receptors. Although Reid et al. (1995) identified VIP- and PACAP-immunoreactive-like substances in nerve fibres in the vicinity of piscine chromaffin tissue, it is unclear as to which one or both of these neuropeptides play a role in catecholamine secretion. However, given the inability of the specific PACAP type I receptors antagonist (PACAP 6-27) to reduce adrenaline secretion in response to VIP and PACAP, it is possible that VIP, rather than PACAP, is responsible for the noncholinergic component of the neuronal regulation of adrenaline secretion from trout chromaffin cells.

The precise mechanisms underlying the initiation of catecholamine secretion by VIP/PACAP from trout chromaffin cells are not known. However, owing to the specific requirement of $\mathrm{Ca}^{2+}$ in the secretory process (Burgoyne et al. 1993, Furimsky et al. 1996), pathways for increasing intracellular $\mathrm{Ca}^{2+}$ are probably responsible. VIP and PACAP receptors belong to a seven transmembrane spanning domain G-protein coupled receptor superfamily and are coupled to adenylyl cyclase and phospholipase C (Ishihara et al. 1992, Lutz et al. 1993, Spengler et al. 1993, Wong et al. 1998). Indeed, in non-piscine chromaffin cells, VIP or PACAP receptor stimulation is associated with an elevation of cAMP, inositol 1,4,5-triphosphate and diacylglycerol, which are believed to promote the entry of extracellular $\mathrm{Ca}^{2+}$ as well as stimulating the release of $\mathrm{Ca}^{2+}$ from intracellular stores (Malhotra et al. 1989, Isobe et al. 1993, Przywara et al. 1996, Tanaka et al. 1996).

The use of heterologous peptides in this study may explain some of the inter-species differences in the degree of potency of VIP and PACAP in stimulating adrenaline secretion from chromaffin cells. This is unlikely, however, because the amino acid sequence of different vertebrate VIPs has been strongly conserved and most substitutions are conservative suggesting that the evolutionary pressure to conserve the VIP molecule has been strong. Indeed, in trout, the VIP amino acid sequence differs from the cod, dogfish, porcine and chicken VIPs at the 3, 6, 4 and 1 positions respectively (Nilsson 1975, Dimaline et al. 1987, Thwaites et al. 1989, Holmgren \& Jensen 1994, Wang \& Conlon 1995). While the trout PACAP amino acid sequence has not been analysed, PACAPs throughout other vertebrates (rat, sheep, mouse, human, amphibian, chicken and teleost fish) also share a high degree of sequence similarity (Wong et al. 1998). Additionally, PACAP shares $66-68 \%$ sequence similarity with VIP. In mammalian and fish species, these structural differences 
appear to have little effect on their biological functions. Indeed, porcine, cod and dogfish VIP were equipotent in stimulating amylase secretion and displacement of radioligand from guinea pig pancreatic acini (Dimaline et al. 1987). Moreover, porcine VIP was able to inhibit cholecystokinin-induced gall bladder contraction in trout (Aldman \& Holmgren 1992) and to relax smooth muscle in the rectum and swim bladder in the cod (Lundin \& Holmgren 1984). Similarly, different forms of PACAP (frog, zebrafish and ovine) were able to stimulate growth hormone secretion with more or else similar potencies from goldfish pituitary cells (Wong et al. 1998).

\section{Relative contribution of cholinergic and non-cholinergic neurotransmitters in the neuronal control of catecholamine secretion}

The differential participation of cholinergic and peptidergic neurotransmitters in the neural control of catecholamine secretion in response to different levels of preganglionic nerve activity has been reported for mammals (Malhotra \& Wakade 1987, Wakade et al. 1991, Guo $\&$ Wakade 1994). In agreement with those investigations, the present study demonstrated that cholinergic stimulation predominated during high frequencies of electrical stimulation while the non-cholinergic component prevailed at low frequencies of stimulation.

In addition to assessing the relative contribution of cholinergic and non-cholinergic neurotransmitters in the neural control of catecholamine secretion from trout chromaffin cells, this study has identified a non-cholinergic component. The observed reduction in catecholamine secretion during low-frequency stimulation in preparations previously treated with the VIP receptor antagonist, VIP 6-28, strongly suggests the participation of the neuropeptides, VIP and/or PACAP. The reduction in noradrenaline secretion was, however, unexpected given the predominant effect of VIP and PACAP on adrenaline secretion. It is clear that cholinergic stimulation, although less prevalent, participates at low frequencies of stimulation with respect to noradrenaline secretion. Based on these results, direct VIP receptor stimulation may interact with cholinergic pathways to regulate noradrenaline secretion from trout chromaffin cells. The precise mechanisms of this interaction remains unknown. To conclusively determine the relative involvement of VIP and PACAP, future studies need to identify which peptides are secreted from the preganglionic nerve terminals during electrical stimulation of these nerves.

Overall, the results of the present investigation demonstrate that the neuronal control of catecholamine secretion in teleost fish may not be confined to cholinergic-evoked events. Indeed, the results suggest that VIP and/or PACAP may act as neurotransmitters and be directly involved in the neuronal stimulation of adrenaline secretion from piscine chromaffin cells, especially at low levels of neuronal activity. Furthermore, the fact that the VIP receptor antagonist (VIP 6-28) greatly reduced adrenaline secretion in response to both VIP and PACAP, together with the observation that both neuropeptides stimulated the secretion of adrenaline with similar potencies, suggest that the VIP- and PACAP-evoked secretion was mediated by PACAP type II (VIP) receptors. This is in marked contrast to the situation in non-piscine chromaffin cells in which PACAP rather than VIP is believed to be more important in mediating the neuronal non-cholinergic component to adrenaline secretion.

\section{Acknowledgements}

This work was financed by National Science and Engineering Research Council (NSERC) of Canada Research and Equipment grants to S F P. C J M was the recipient of an NSERC postgraduate scholarship.

\section{References}

Abele B, Hathaway CB, Nibbio B \& Epple A 1998 Electrostimulation of catecholamine release in the eel: modulation by antagonists and autocrine agonists. General and Comparative Endocrinology 109 366-374.

Aldman \& Holmgren S 1992 VIP inhibits CCK-induced gall bladder contraction involving a beta-adrenoceptor mediated pathway in the rainbow trout, Oncorhynchus mykiss, in vivo. General and Comparative Endocrinology 88 287-291.

Al-Kharrat H, Weiss U, Tran Q, Nibbio B, Scholz S \& Epple A 1997 Cholinergic control of catecholamine release in the eel. General and Comparative Endocrinology 108 102-108.

Bodanszky M, Klausner YS \& Said SI 1973 Biological activities of synthetic peptides corresponding to fragments of and to the entire sequence of the vasoactive intestinal peptide. PNAS $\mathbf{7 0}$ 382-384.

Burgoyne RD, Morgan A, Robinson I, Pender N \& Cheek T 1993 Exocytosis in adrenal chromaffin cells. Journal of Anatomy $\mathbf{1 8 3}$ 309-314.

Chow BKC 1997 The goldfish vasoactive intestinal polypeptide receptor: functional studies and tissue distribution. Fish Physiology and Biochemistry 17 213-222.

Dimaline R, Young J, Thwaites DT, Lee CM, Shuttleworth TJ \& Thorndyke MC 1987 A novel vasoactive intestinal peptide (VIP) from elasmobranch intestine has full affinity for mammalian pancreatic VIP receptors. Biochimica et Biophysica Acta 930 97-100.

Epple A 1993 Adrenomedullary catecholamines. In The Endocrinology of Growth, Development and Metabolism in Vertebrates, pp 327-343. Eds MP Schreibman, CG Scanes \& PKT Pang. San Diego: Academic Press.

Epple A, Brinn JE \& Gill TS 1995 The evolution of the adrenal medulla. In Embryos, Endocrine Cells and the Neural Crest, pp 125-140. Eds B Kramer \& B Rawdon. Johannesburg: Witwatersand University Press.

Fabbri E, Capuzzo A \& Moon TW 1998 The role of circulating catecholamines in the regulation of fish metabolism: an overview. Comparative Biochemistry and Physiology C 120 177-192.

Fishbein VA, Coy DH, Hocart SJ, Jiang NY, Mrozinski JE, Mantey SA \& Jensen RT 1994 A chimeric VIP-PACAP analogue but not VIP pseudopeptides function as VIP receptor antagonists. Peptides 15 95-100. 
Fritsche R, Reid SG, Thomas S \& Perry SF 1993 Serotonin-mediated release of catecholamines in the rainbow trout Oncorhynchus mykiss. Journal of Experimental Biology 178 191-204.

Furimsky M, Moon TW \& Perry SF 1996 Calcium signalling in isolated single chromaffin cells of the rainbow trout (Oncorhynchus mykiss). Journal of Comparative Physiology B 166 396-404.

Gallo VP, Civinini A, Mastrolia L, Leitner G \& Porta S 1993 Cytological and biochemical studies on chromaffin cells in the head kidney of Gasterosteus aculeatus (Teleostei, Gasterosteidae). General and Comparative Endocrinology 92 133-142.

Gaspo R, Lamarche L, deChamplain J \& Yamaguchi N 1997 Canine adrenal catecholamine response to VIP is blocked by PACAP-(6-27) in vivo. American Journal of Physiology 272 R1606-R1612.

Gfell B, Kloas W \& Hanke W 1997 Neuroendocrine effects on adrenal hormone secretion in carp (Cyprinus carpio). General and Comparative Endocrinology 102 310-319.

Guo X \& Wakade AR 1994 Differential secretion of catecholamines in response to peptidergic and cholinergic transmitters in rat adrenals. Journal of Physiology 475 539-545.

Holmgren S 1985 Neuropeptides functions in the fish gut. Peptides 6 (Suppl 3) 363-368.

Holmgren S 1995 Neuropeptide control of the cardiovascular system in fish and reptiles. Brazilian Journal of Medical and Biological Research 28 1207-1216

Holmgren S \& Jensen J 1994 Comparative aspects on the biochemical identity of neurotransmitters of autonomic neurons. In Comparative Physiology and Evolution of the Autonomic Nervous System, pp 69-95. Eds S Nilsson \& S Holmgren. Switzerland: Harwood Academic Publishers.

Ishihara T, Shigemoto R, Mori K, Takahashi K \& Nagata S 1992 Functional expression and tissue distribution of a novel receptor for vasoactive intestinal polypeptide. Neuron 8 811-819.

Isobe K, Nakai T \& Takuwa Y $1993 \mathrm{Ca}^{2+}$-dependent stimulatory effect of pituitary adenylate cyclase-activating polypeptide on catecholamine secretion from cultured porcine adrenal medullary chromaffin cells. Endocrinology 132 1757-1765.

Lundin K \& Holmgren S 1984 Vasoactive intestinal polypeptide-like immunoreactivity and effects of VIP in the swim bladder of the cod, Gadus morhua. Journal of Comparative Physiology B 154 627-633.

Lutz E-M, Sheward WJ, West KM, Morrow JA, Fink G \& Harmar AJ 1993 The VIP2 receptor: molecular characterization of a cDNA encoding a novel receptor for vasoactive intestinal peptide. FEBS Letters $3343-8$

Malhotra RK \& Wakade AR 1987 Non-cholinergic component of rat splanchnic nerves predominates at low neuronal activity and is eliminated by naloxone. Journal of Physiology 383 639-652.

Malhotra RK, Wakade TD \& Wakade AR 1989 Crosscommunication between acetylcholine and VIP in controlling catecholamine secretion by affecting cAMP, inositol triphosphate, protein kinase $\mathrm{C}$, and calcium in rat adrenal medulla. Journal of Neuroscience 9 4150-4157.

Misbahuddin M, Oka M, Nakanishi A \& Morita K 1988 Stimulatory effect of vasoactive intestinal polypeptide on catecholamine secretion from isolated guinea pig adrenal chromaffin cells. Neuroscience Letters 92 202-206.

Montpetit CJ \& Perry SF 1999 Neuronal control of catecholamine secretion from chromaffin cells in the rainbow trout (Oncorhynchus mykiss). Journal of Experimental Biology 202 2059-2069.

Nandi J 1961 New arrangement of interrenal and chromaffin tissues of teleost fishes. Science 134 389-390.

Nilsson A 1975 Structure of the vasoactive intestinal octasopeptide from chicken intestine. The amino acid sequence. FEBS Letters $\mathbf{6 0}$ 322-326.

Nilsson S, Abrahamsson T \& Grove DJ 1976 Sympathetic nervous control of adrenaline release from the head kidney of the cod,
Gadus morhua. Comparative Biochemistry and Physiology C 55 123-127.

Przywara DA, Guo X, Lu Angellis M, Wakade TD \& Wakade AR 1996 A non-cholinergic transmitter, pituitary adenylate cyclaseactivating polypeptide, utilizes a novel mechanism to evoke catecholamine secretion in rat adrenal chromaffin cells. Journal of Biological Chemistry 271 10545-10550.

Randall DJ \& Perry SF 1992 Catecholamines. In Fish Physiology: The Cardiovascular System, vol 12B, pp 255-300. Eds DJ Randall \& WS Hoar. New York: Academic Press.

Reid SG \& Perry SF 1995 Cholinoceptor-mediated control of catecholamine release from chromaffin cells in the American eel, Anguilla rostrata. Journal of Comparative Physiology B 165 464-470.

Reid SG, Fritsche R \& Jonsson AC 1995 Immunohistochemical localization of bioactive peptides and amines associated with the chromaffin tissue of five species of fish. Cell and Tissue Research 280 499-512.

Reid SG, Bernier N \& Perry SF 1998 The adrenergic stress response in fish: control of catecholamine storage and release. Comparative Biochemistry and Physiology C 120 1-27.

Robberecht P, Woussen-Colle M, DeNeef P, Gourlet P, Buscail L, Vandermeers A, Vandermeers-Piret MC \& Christophe J 1991 The two forms of the pituitary adenylate cyclase activating polypeptide (PACAP (1-27) and PACAP (1-38)) interact with distinct receptors on rat pancreatic AR 4-2J cell membranes. FEBS Letters $286133-136$.

Spengler D, Waeber C, Pantaloni C, Holsboer F, Bockaer J, Seeburg PH \& Journot L 1993 Differential signal transduction by five splice variants of the PACAP receptor. Nature 365 170-175.

Tanaka K, Shibuya I, Nagatomo T, Yamashita H \& Kanno T 1996 Pituitary adenylate cyclase-activating polypeptide causes rapid $\mathrm{Ca}^{2+}$ release from intracellular stores and long lasting $\mathrm{Ca}^{2+}$ influx mediated by $\mathrm{Na}^{+}$influx-dependent membrane depolarization in bovine adrenal chromaffin cells. Endocrinology 137 956-966.

Thwaites DT, Young J, Thorndyke MC \& Dimaline R 1989 The isolation and chemical characterization of a novel vasoactive intestinal peptide-related peptide from a teleost fish, the cod, Gadus morhua. Biochimica et Biophysica Acta 999 217-220.

Wakade TD, Blank MA, Malhotra RK, Pourcho R \& Wakade AR 1991 The peptide VIP is a neurotransmitter in rat adrenal medulla: physiological role in controlling catecholamine secretion. Journal of Physiology 444 349-362.

Wang Y \& Conlon JM 1995 Purification and structural characterization of vasoactive intestinal polypeptide from the trout and bowfin. General and Comparative Endocrinology 98 94-101.

Watanabe T, Masuo Y, Matsumoto H, Suzuki N, Ohtaki T, Masuda Y, Kitada C, Tsuda M \& Fujino M 1992 Pituitary adenylate cyclase activating polypeptide provokes cultured rat chromaffin cells to secrete adrenaline. Biochemical and Biophysical Research Communications 182 403-411.

Watanabe T, Shimamoto N, Takahashi A \& Fujino M 1995 PACAP stimulates catecholamine release from the adrenal medulla: a novel noncholinergic secretagogue. American Journal of Physiology 269 E903-E909.

Wei Y, Martin SC, Heinrich G \& Mojsov S 1998 Cloning and functional characterization of PACAP specific receptors in zebrafish. Annals of the New York Academy of Sciences 865 45-48.

Wendelaar-Bonga SE 1997 The stress response in fish. Physiological Reviews 77 591-625.

Wolf K 1963 Physiological salines for freshwater teleosts. Progress in Fish Culture 25 135-140.

Wong AOL, Leung MY, Shea WLC, Tse LY, Chang JP \& Chow BKC 1998 Hypophysiotropic action of pituitary adenylate cyclase-activating polypeptide (PACAP) in the goldfish: immunohistochemical demonstration of PACAP in the pituitary, 
PACAP stimulation of growth hormone release from pituitary cells, and molecular cloning of pituitary type I PACAP receptor.

Endocrinology 1393465-3479.

Woodward JJ 1982 Plasma catecholamines in resting rainbow trout, Salmo gairdneri Richardson, by high pressure liquid chromatography. Journal of Fish Biology 21 429-432.

Yamaguchi N 1993 in vivo evidence for adrenal catecholamine release mediated by nonnicotinic mechanisms: local medullary effect of VIP. American Journal of Physiology 265 R76-R771.
Yon L, Chartrel N, Feuilloley M, deMarchis S, Fournier A, deRijk E, Pelletier G, Roubos E \& Vaudry H 1994 Pituitary adenylate cyclase-activating polypeptide stimulates both adrenocortical cells and chromaffin cells in the frog adrenal gland. Endocrinology 135 2749-2758.

Received 22 February 2000

Accepted 10 May 2000 